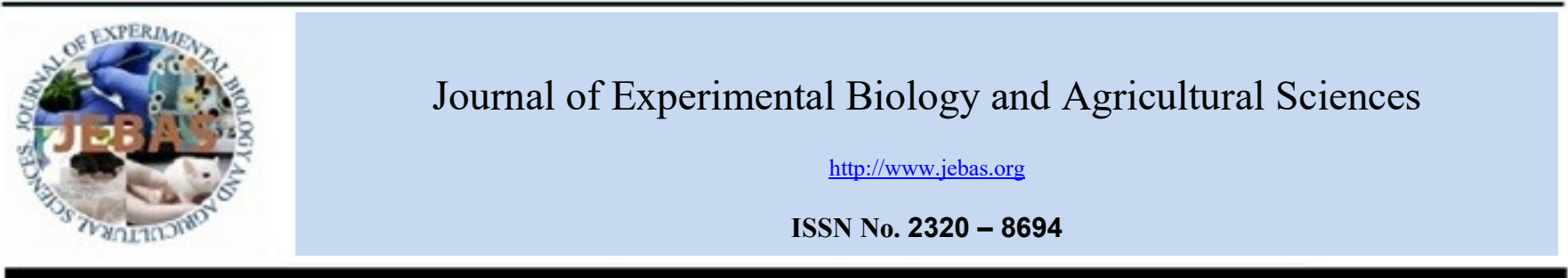

\title{
IMPACT OF FEED SUBSIDY REMOVAL ON THE ECONOMIC SUCCESS OF SMALL RUMINANT FARMING IN NORTHERN BADIA OF JORDAN
}

\author{
Ja'far Mansur Al-Khaza'leh* \\ Faculty of Agricultural Technology, Al-Balqa Applied University, P.O. Box 19117, Al-Salt, Jordan \\ Received - February 12, 2020; Revision - March 15, 2020; Accepted - March 28, 2020 \\ Available Online - April 25, 2020 \\ DOI: http://dx.doi.org/10.18006/2020.8(2).193.200
}

KEYWORDS
In-kind benefits
Intangible benefits
Gross margin
Net benefit
Economic success

\begin{abstract}
The small ruminant sector contributes substantially to food security and the livelihoods of farmers in Jordan. Subsidy on feed for the livestock sector is considered to be an important policy for maintaining feed prices low, thus improving the livelihood of the households. This study aimed to evaluate the effect of feed subsidy removal on the economic success of small ruminant production in two production systems in northern Badia of Jordan. Data was collected by questionnaire survey administered to 120 small ruminant farmers. Gross margin (GM1 and GM2) and net benefit (NB) were used to measure the economic success of small ruminant production. GM1 constitutes cash revenue of sheep and goats, while GM2 additionally includes in-kind benefits (meat and milk consumption). NB comprises cash revenue, in-kind benefits and intangible benefits (insurance and finance). The feed price was significantly affected by feed subsidy removal $(\mathrm{p}<0.05)$. Feed subsidy removal negatively $(\mathrm{p}<0.05)$ affected all the parameters of the economic success of small ruminant production. GM1, GM2 and NB per farm with subsidized feed prices were significantly $(\mathrm{p}<0.05)$ higher than farms without subsidized feed prices in both production systems. A $36 \%$ of farms with feed subsidy had a negative NB compared to $54 \%$ of farms without feed subsidy. Findings of current study revealed that under conditions of forage shortage in rangelands and high feed prices, feed subsidy removal has a negative impact on the parameters of the economic success of small ruminant production and can threaten the income and livelihoods of farmers. Keeping subsidies on the feed aimed at livestock keepers is a good policy to alleviate the detrimental impact on households.
\end{abstract}

* Corresponding author

E-mail: jkhaza@bau.edu.jo (Ja'far Mansur Al-Khaza’leh)

Peer review under responsibility of Journal of Experimental Biology and Agricultural Sciences.

Production and Hosting by Horizon Publisher India [HPI] (http://www.horizonpublisherindia.in/).

All rights reserved.
All the articles published by Journal of Experimental Biology and Agricultural Sciences are licensed under a Creative Commons Attribution-NonCommercial 4.0 International License Based on a work at www.jebas.org.

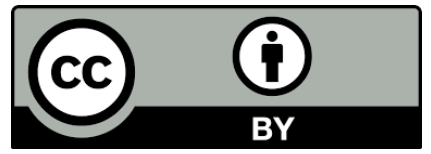




\section{Introduction}

In Jordan, sheep and goats play a considerable role in the economy, food security and livelihoods of farmers of rural areas (Al-Atiyat \& Tabbaa, 2009; Al-Atiyat, 2014). Small ruminants are well adapted to the arid and semi-arid conditions of the country representing the highest proportion of livestock biomass, with an estimated population of about $3,063,120$ head of sheep and 772,670 head of goats in 2017 (Department of Statistics, 2017). Small ruminants are raised under different production systems (Abu-Zanat et al., 2005; Alrousan, 2009). Two major production systems which used in the country are: transhumant production system (pastoral) which is the prevalent production system and the sedentary production system (agro-pastoral), which is practiced in the villages and peri-urban parts of the country.

A sufficient provision of feed is necessary for livestock to ensure their production and health status. The scarcity of water resources, shortage of rangeland and feed are major constraints for small ruminant production in Jordan (Al-Karaki \& Al-Momani 2011; AlKhaza'leh et al., 2015a). In Jordan, pastures with low nutritional quality and poor biomass are inadequate for feeding small ruminant animals (Obeidat et al., 2014). Therefore, animals are supplemented with concentrates which are a shortage and costly in order to meet their nutrient needs (Alshdaifat \& Obeidat, 2019). Moreover, the total yield of rained and irrigated barley production as a major concentrates in Jordan was 394,277 tons in 2016 (Ministry of Agriculture, 2016) which is not enough to feed livestock. Therefore, the Jordanian government depends on importing feedstuff from other countries, which in turn has a significant impact on Jordan's GDP (Ministry of Industry Trade and Supply, 2018).

Price subsidy on feed is a prevalent policy in many developing countries like Jordan. The price of feed in Jordan for the livestock sector had been subsidized by the government for many years. Nevertheless, the subsidy on feed is one of the most existing volatile agro-economic policies in Jordan impacting its budgetary. The feed subsidy is an important instrument for the livelihood of farmers Taking into account that feed price in Jordan is the greatest variable expenses in the sheep and goat industry, stopping feed subsidy could have a considerable effect on livestock production, incomes, expenses, profitability, the economic performance of small ruminants and thus on the sustainability of sheep and goat farming. The economic consequences of feed subsidy removal on sheep and goat farming were not adequately investigated in Jordan and hence there is a need for in-depth analysis including cost-benefits to determine the impact of subsidy removal on sustaining small ruminant production. In the light of this background, the objectives of the present study were to evaluate the economic performance of small ruminants and to analyze the impact of feed subsidy lifting on the economic success of small ruminant production in two production systems of Jordan.

\section{Materials and Methods}

\subsection{The study area and production systems}

The study was carried out in the northern Badia of Jordan east of the Mafarq governorate. The term "Badia" refers to desert or arid region, dwelled by Bedouins or Badu. The northern Badia constituted $36 \%$ of the total area of Jordanian Badia $\left(\mathrm{km}^{2}=71,474\right.$ which constitutes $80 \%$ of the total area of Jordan). The study area is characterized by transhumant production system (pastoral, the herders practice two major patterns of seasonal mobility: toward east "al tashreeg"' to benefit from grazing on the vegetation during late winter and early spring and back toward west "al taghreeb" after that) and sedentary production system (agro-pastoral). The northern Badia has arid climate and it has been affected frequently by drought cycles, receiving a total annual rainfall of about 116 $\mathrm{mm}$. Therefore, water and pasture biomass availability in the study area are low.

Sheep and goats are the predominant animal species representing the major small ruminant production systems in the northern Badia. According to secondary data obtained from the study region's agricultural offices in 2017 , the livestock population in the study area is estimated to be about 366,940 head of sheep, 61,210 head of goats, 3,020 head of cattle, 1,130 head of camels. The same secondary data showed that in 2017, the total population of sheep and goats keepers was 3,150 . For the same year, the small ruminant population in the study area constituted $12 \%$ sheep and $7.9 \%$ goats of the total population of sheep and goats in Jordan, respectively.

\subsection{Sampling and data collection}

For this study, a list of all small ruminant keepers and their livestock holdings in each village within administrative unit of the study area was obtained from local officials of the Ministry of Agriculture. Farmers, who kept at least 10 adult animals in the flocks, were identified from the list of farmers and systematic random sampling at the third name was used to select 120 farmers for the interview by the assistance of key informant. In general, 5 farmers were replaced by the next one during conducting the actual questionnaire survey. Accordingly, a sample of 62 farms was assigned for transhumant production system and 58 farms for sedentary production system. Data were collected between December 2017 and March 2018 using a structured questionnaire format. Suitability of questionnaire survey to the farmers in the study area regarding the language and the logical flow was assured before conducting the actual questionnaire survey. 
The questionnaires captured information regarding socio-economic variables, livestock holdings, animal productivity, input and output parameters and annual production costs and revenues generation in the last 12 months. In addition to the survey method, secondary data on the number of small ruminants and small ruminant keepers, water and feed prices were obtained from water and agricultural offices of the study area. Moreover, climate data including amount of rainfall and temperature in the study area were acquired from Meteorological Department of Jordan.

\subsection{Economic performance of small ruminant production}

The major variable costs (VC) from small ruminant production comprised purchased feedstuff cost, stubble grazing cost, water cost, veterinary cost, hired labor cost and transportation cost. Stubble grazing cost included fees for rented land for grazing. Hired labor cost included the wage payment given for either the continuous or seasonal herders. Transportation costs comprised costs for water, feed and animal transport. The annual costs of housing and machinery were not considered in the study due to depreciation and simplicity of material used in animal housing.Veterinary costs included expenses on medications and vaccinations.

In the present study, the cash revenues (CR) from small ruminant production included the sale of animals, milk and dairy products. For home consumption, the unit price of each product was estimated based on the farm gate price. In-kind benefits (IK) comprised the values of meat and milk consumption. The monetary values of manure, wool and hair were negligible and not considered in the calculations because most of farmers in the study area did not market or use them. Intangible socio-economic benefits of goat production included financial (F) and insurance (I). The financial benefit of flock per household was valued as follows: (number of animals owned $\mathrm{X}$ respective market price of animals) $\mathrm{X}$ interest rate of the finance (3.6\%, based on Central Bank of Jordan monthly reviews 2016/2017). The insurance value of flock per household was estimated as follows: (average monetary values of the flock per household) $\mathrm{X}$ the insurance factor (3.6\%, based on Central Bank of Jordan monthly reviews 2016/2017).

The economic parameters (in JD farm ${ }^{-1}$ year $^{-1}$ ) were valued by using the following equations:

$G M 1=C R-V C$
$G M 2=(C R+I K)-V C$
$N B=(C R+I K+F+I)-(V C)$

Where: GM is the gross margin, NB is the net benefit. Other acronyms are previously defined. All economic parameters are given in JD (Jordanian Dinar) whereby $1 \mathrm{JD}$ equivalent to $1.4 \mathrm{US}$ dollars in the year 2017.

\subsection{The policy of feed subsidy}

The government allocates the subsidy in the rate of 10 to $15 \mathrm{~kg}$ per head per month for sheep and goat owners who have a certificate/fodder card (indicates the share of subsidized feed based on the livestock holdings). All the farmers interviewed had the fodder card and received the benefit from fodder subsidies. The value of subsidy was calculated as the difference between the actual selling price of feed to farmers and the international market price. In the present study, the subsidized price for barley and wheat bran was $175 \mathrm{JD} /$ ton and $77 \mathrm{JD} /$ ton, respectively, while the unsubsidized market price for barley and wheat bran used for calculations was $235 \mathrm{JD} /$ ton and $140 \mathrm{JD} /$ ton, respectively, in 2017. Thus, the percentage of the subsidized price for barley and wheat bran was $25 \%$ and $45 \%$, respectively, below the international market price. The average percentage difference of barley and wheat bran was added for unsubsidized feed and used for calculation.

\subsection{Statistical analysis}

Households' socio-economic characteristics and flock ownership were descriptively summarized by their frequencies, means and percentages. Chi-square test for proportions of categorical variables and the $t$-test for continuous variables were applied after checking the normal distribution of residuals to compare the two production systems. The variable costs, revenues and economic efficiency parameters were not normally distributed. Hence, the Wilcoxon-Mann-Whitney test (Bergmann et al., 2000) was employed to detect significant differences in the mean values of variables between subsidized and unsubsidized feed and among transhumant and sedentary systems. The analyses were performed using SAS version 9.3 (SAS Institute, 2012). For providing overall ranking of purposes of keeping small ruminants, indices were calculated and ranks were based on the first five choices of priority characteristics in order of importance by respondent (i.e. 5= highest importance, $1=$ lowest importance) and were calculated as : index $=$ sum of $[5$ for rank $1+4$ for rank $2+3$ for rank $3+2$ for rank $4+1$ for rank 5 for specific purpose] divided by the sum [ 5 for rank $1+4$ for rank $2+3$ for rank $3+2$ for rank $4+1$ for rank 5] for all purposes of keeping small ruminants.

\section{Results}

\subsection{Household characteristics}

Small ruminant owners indicated that all households were maleheaded, with average age of 49 years, average household size of 10 members, and average experience of 36 years in livestock husbandry. The majority of the respondents $(77.6 \%)$ in the sedentary system depend on family labor for herding and caring animals while the transhumant systems $(45.2 \%)$ had more either 
continuous or seasonal labor. The illiteracy rate among the household heads was higher in the transhumant $(51.6 \%)$, while the sedentary system had more educated household heads $(75.9 \%)$. The majority of farmers kept mixed species of sheep and goats, and sheep was the most dominant livestock species owned by the majority of farmers. The local Awassi breed is the major and abundant sheep breeds in the study area and few farmers keep Naemi and Najdi sheep breeds. For goats, the major goat breeds prevailing in the study area were northern desert goat followed by Mountain Black and crossbreds. The proportion of households kept sheep was higher in the transhumant than in the sedentary system $(100 \%$ vs $81 \%)$. The present study also recorded a significantly higher $(\mathrm{P}<0.05)$ number of sheep in the transhumant compared to the sedentary system (468 vs. 170 head), but a marginal difference $(\mathrm{P}=0.0861)$ was observed for goat flock size (74 vs. 45 head $)$ However, the overall small ruminants flock sizes were significantly higher in transhumant than in the sedentary $(\mathrm{P}<0.05)$.

\subsection{The benefit of keeping small ruminants}

The reasons for keeping small ruminants are shown in Figure 1. Though most households kept sheep and goats for multiple purposes, the highest benefit from keeping of sheep and goats was cash generating followed by savings, milk production, meat production for home consumption, and manure.

The estimated monetary values of small ruminant benefits to the households in each production system are presented in Table 1. The highest benefit from keeping sheep and goats in the surveyed households was from live sales of animals, followed by meat consumption, insurance, finance, and milk consumption. Economic benefits from milk consumption were the lowest in the two production systems. Small ruminants slaughtered and meat consumed by households or used for social events or sacrificed during religious festivities. As a livelihood strategy of households to increase cash liquidity of sheep lambs and goat kids of less than one year were sold most often, followed by mature males while mature

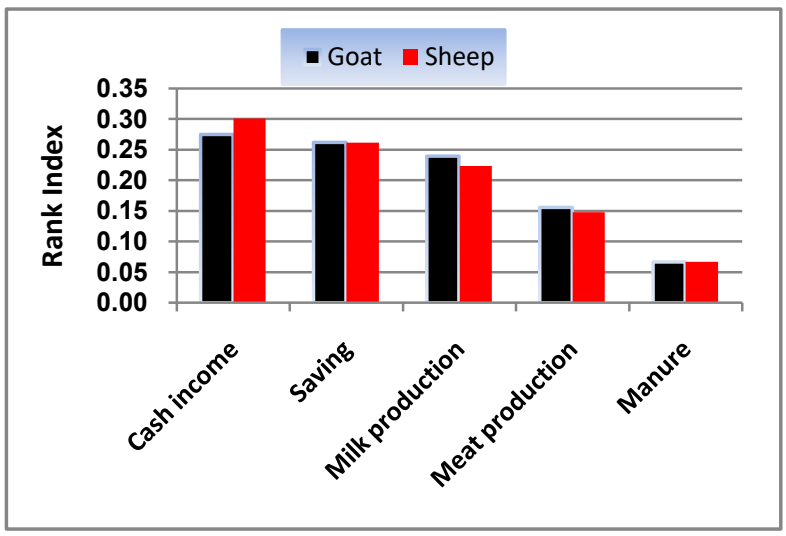

Figure 1 Reasons for keeping small ruminants and the ranking of the importance of these reasons (Index based on rank weights of the choices of priority characteristics i.e. $5=$ highest importance).

females had a lower share of sales. The average annual off-take rate for live sale of small ruminants was significantly $(\mathrm{P}<0.0001)$ higher in the transhumant system than the sedentary system.

\subsection{The cost of keeping small ruminants}

Costs of small ruminant keeping among the production systems are presented in Table 2. The total variable costs among production systems varied significantly $(\mathrm{P}<0.05)$. A significantly $(\mathrm{P}<0.05)$ higher feed costs in the transhumant than in the sedentary systems were observed and the feed costs represented the largest share of the total variable costs in the transhumant (74.8\%) and sedentary $(75.1 \%)$ systems. However, the difference among systems in the costs of rented land for grazing was not significant $(\mathrm{P}>0.05)$. Water costs were not significantly different among production systems and accounted for the lowest share (1.2\% vs $2.2 \%$ ) of the total variable costs in the transhumant and sedentary systems, respectively. The other variable costs, namely veterinary, transportation and hired labor were significantly $(\mathrm{P}<0.05)$ higher in the transhumant than in the sedentary systems.

Table 1 Estimated small ruminant benefits from live sales, meat and milk consumption, and intangible functions to the households in two production systems of Jordan in the year 2017.

\begin{tabular}{|ccccc|}
\hline & \multicolumn{2}{c}{ Transhumant(n=62) } & \multicolumn{2}{c|}{ Sedentary(n=58) } \\
& Value (JD) & \% of total & Value (JD) & 69.5 \\
\hline Live sales & $2,060,500$ & 71.4 & 700,950 & 4.8 \\
\hline Milk & 146,771 & 5.1 & 48,588 & 10.4 \\
\hline Meat & 206,150 & 7.1 & 105,300 & 6.8 \\
\hline Financial & 212,292 & 7.4 & 68,220 & 8.5 \\
\hline Insurance & 260,520 & 9.0 & 85,922 & 100 \\
\hline Total & $2,886,233$ & 100 & $1,008,980$ & \\
\hline
\end{tabular}

$\mathrm{JD}=$ Local currency $(1 \mathrm{JD}=1.4 \mathrm{USD}$ in 2017) 
Table 2 Variable costs of small ruminant rearing in two production systems of Jordan in the year 2017

\begin{tabular}{|c|c|c|c|c|c|}
\hline \multirow[t]{3}{*}{ Parameters (JD) } & \multicolumn{5}{|c|}{ Production systems } \\
\hline & \multicolumn{2}{|c|}{ Transhumant(n=62) } & \multicolumn{2}{|c|}{ Sedentary $(\mathrm{n}=58)$} & \multirow[t]{2}{*}{ P-value } \\
\hline & Mean & Median & Mean & Median & \\
\hline Feed costs & $26,343.2$ & $15,000.0^{\mathrm{a}}$ & $9,183.1$ & $4,800.0^{\mathrm{b}}$ & $<.0001$ \\
\hline Grazing costs & $1,881.0$ & $0.0^{\mathrm{a}}$ & 795.3 & $97.5^{\mathrm{a}}$ & 0.8586 \\
\hline Water costs & 428.8 & $37.5^{\mathrm{a}}$ & 266.2 & $120.0^{\mathrm{a}}$ & 0.4009 \\
\hline Veterinary costs & 530.9 & $240.0^{\mathrm{a}}$ & 259.4 & $120.0^{\mathrm{b}}$ & 0.0001 \\
\hline Transportation costs & $3,401.5$ & $2,400.0^{\mathrm{a}}$ & $1,102.8$ & $420.0^{b}$ & $<.0001$ \\
\hline Hired labor cots & $2,614.8$ & $0.0^{\mathrm{a}}$ & 625.3 & $0.0^{\mathrm{b}}$ & 0.0002 \\
\hline Total variable costs & $35,200.1$ & $19,610.0^{\mathrm{a}}$ & $12,232.1$ & $6,180.0^{\mathrm{b}}$ & $<.0001$ \\
\hline
\end{tabular}

$\mathrm{JD}=$ Local currency $([1 \mathrm{JD}=1.4 \mathrm{USD}]$ in 2017); Pairs of variables per flock in the transhumant and sedentary systems with different superscripts are statistically significant.

Table 3 Economic efficiency of small ruminants rearing in two production systems of Jordan in the year 2017

\begin{tabular}{|c|c|c|c|c|c|}
\hline \multirow[t]{3}{*}{ Parameters (JD) } & \multicolumn{5}{|c|}{ Production systems } \\
\hline & \multicolumn{2}{|c|}{ Transhumant(n=62) } & \multicolumn{2}{|c|}{ Sedentary $(\mathrm{n}=58)$} & \multirow[t]{2}{*}{ P-value } \\
\hline & Mean & Median & Mean & Median & \\
\hline Total variable costs/head & 62.7 & $61.5^{\mathrm{a}}$ & 58.8 & $53.0^{\mathrm{a}}$ & 0.2383 \\
\hline GM1/flock & 401.0 & $-1,845.0^{\mathrm{a}}$ & 691.0 & $-902.5^{\mathrm{a}}$ & 0.6031 \\
\hline GM1/head & -2.6 & $-6.0^{\mathrm{a}}$ & -14.3 & $-12.0^{\mathrm{b}}$ & 0.0483 \\
\hline GM2/flock & $3,726.0$ & $70.0^{\mathrm{a}}$ & $2,506.5$ & $101.0^{\mathrm{a}}$ & 0.9686 \\
\hline GM2/head & 4.9 & $0.0^{\mathrm{a}}$ & -2.5 & $2.5^{\mathrm{a}}$ & 0.2134 \\
\hline NB/flock & $11,352.1$ & $3,151.5^{\mathrm{a}}$ & $5,164.1$ & $931.5^{\mathrm{a}}$ & 0.1910 \\
\hline NB/head & 18.7 & $14.0^{\mathrm{a}}$ & 10.4 & $15.5^{\mathrm{a}}$ & 0.1629 \\
\hline
\end{tabular}

$\mathrm{GM}=$ gross margin, $\mathrm{NB}=$ net benefit, JD = Local currency ([1JD = 1.4 USD $]$ in 2012.); Pairs of variables per flock/head in the transhumant and sedentary systems with different superscripts are statistically significant

Table 4 Purchased feed cost per farm with subsidy retained and without the subsidy of the different production systems in the year 2017

\begin{tabular}{|c|c|c|c|c|}
\hline \multirow{3}{*}{ Variable } & \multicolumn{4}{|c|}{ Production system } \\
\hline & \multicolumn{2}{|c|}{ Transhumant $(\mathrm{n}=62)$} & \multicolumn{2}{|c|}{ Sedentary $(\mathrm{n}=58)$} \\
\hline & Mean (JD) & Median & Mean (JD) & Median \\
\hline Subsidized & $26,343.2$ & $15,000.0^{\mathrm{a}}$ & $9,183.1$ & $4,800.0^{b}$ \\
\hline Unsubsidized & $35,563.3$ & $20,250.0^{\mathrm{a}}$ & $12,397.2$ & $6,480.0^{\mathrm{b}}$ \\
\hline
\end{tabular}

JD = Jordanian Dinar ( $1 \mathrm{JD} \approx 1.4$ USD in 2017); Medians with different superscripts in the rows differ significantly $(\mathrm{p}<0.05)$

\subsection{Economic efficiency of small ruminant keeping}

The economic parameters per flock and head among production systems are presented in Table 3. All the economic parameters evaluated in the present study were similar among systems, except for GM1 per head where it was significantly $(\mathrm{P}<0.05)$ higher in the transhumant compared to the sedentary system. In the transhumant system, $58 \%$ and $47 \%$ of farmers had negative values of GM1 and GM2 per head compared to $62 \%$ and $45 \%$ of farmersin the sedentary system, respectively. Thirty-one percent and $33 \%$ of the farmers in the transhumant and sedentary systems, respectively, had a negative NB per head.

\subsection{Feed subsidy removal}

The average of the unsubsidized feed price per farm $(n=120)$ was significantly $(\mathrm{p}<0.05)$ higher than the subsidized feed price $(\mathrm{n}=120)$. The overall median and mean of the subsidized feed price were $10,200 \mathrm{JD}$ and 18,049 JD, respectively while the overall median and mean of the unsubsidized feed price were 13,770 JD and 24,366 JD, respectively. If the feed subsidy was removed, the share of feed cost would increase from $75 \%$ to $80 \%$ of the total variable costs.

The values of feed variable costs per farm with subsidy retained and without subsidy in two production systems are presented in Table 4.The average of the subsidized and unsubsidized feed price 
Table 5Economic efficiency of small ruminantsper farm with feed subsidy retained and without feed subsidy in the year 2017

\begin{tabular}{|ccccc|}
\hline & \multicolumn{2}{c|}{ Feed } & \multicolumn{2}{c|}{ Unsubsidized $(\mathrm{n}=120)$} \\
Parameter (JD) & Mean & Median & Mean & Median \\
\hline GM1 & 541.2 & $-1,242.0^{\mathrm{a}}$ & $-5,776.0$ & $-3,902.5^{\mathrm{b}}$ \\
\hline GM2 & $3,136.6$ & $95.0^{\mathrm{a}}$ & $-3,180.6$ & $-2,422.5^{\mathrm{b}}$ \\
\hline NB & $8,361.2$ & $1,963.0^{\mathrm{a}}$ & $2,044.0$ & $-311.5^{\mathrm{b}}$ \\
\hline
\end{tabular}

$\mathrm{GM}=$ gross margin, NB = net benefit, Pairs of variables of economic parameters with feed subsidy retained and without subsidy with different superscripts differ significantly $(\mathrm{p}<0.05)$; JD = Jordanian Dinar $(1 \mathrm{JD} \approx 1.4$ USD in 2017)

per farm in the transhumant system was significantly $(\mathrm{p}<0.05)$ higher than subsidized and unsubsidizedfeed price in the sedentary system, respectively.

\subsection{Feed subsidy removal and economic efficiency of smal ruminant keeping}

The analysis showed that all economic efficiency parameters per farm with feed subsidy retained and without feed subsidy were significantly different (Table 5). The percentage of farms with subsidized feed prices that had more often a negative GM1 $(\mathrm{GM} 1<0)$ is apparently lower $(60 \%)$ compared to $76 \%$ of farms with unsubsidized feed prices. Regarding the GM2 parameter, $47 \%$ of farms with subsidized feed had a negative GM2 (GM2<0) compared to $68 \%$ of farms with unsubsidized feed prices. GM1 and GM2 per farm with subsidized feed prices were significantly higher than farms with unsubsidized feed prices $(\mathrm{p}<0.05)$.

The cost-benefit ratio per farm with subsidized feed prices was significantly $(\mathrm{p}<0.05)$ higher than farms with unsubsidized feed prices. Thirty-sixpercent of the farms with subsidized feed prices had a negative $\mathrm{NB}(\mathrm{NB}<0)$ compared to $54 \%$ of farms within subsidized feed prices. NB per farm of subsidized feed prices was significantly $(p<0.05)$ higher than those of farmers of unsubsidized feed prices.

\section{Discussion}

Nutrition in livestock production systems is essential and economically crucial. In Jordanian small ruminant farming, nutrition is critical because the share of feed cost constituted the major part of total variable costs impacting productivity and decreasing profitability (Obeidat \& Shdaifat, 2013; Al-Khaza'leh et al., 2015b; Obeidat, 2018). In 2017, feed shared the biggest (94\%) portion of the total physical input values used in small ruminants production in Jordan (Department of Statistics, 2017)

The higher of the subsidized and unsubsidized feed cost observed in the transhumant system than those in the sedentary system in the present study was probably due to the differences in average flock size per farm between systems (483 in transhumant vs 172 in sedentary). The lower of the subsidized feed cost compared to unsubsidized feed cost within the production systems indicating the large gap between the actual subsidized selling price of feed and the free unsubsidized market price. A previous analysis study (Kristjanson \& Tyner, 1992) showed that the effects of subsidy removal would be much larger on livestock when the feed cost forms the biggest portion of the total costs.

In this study, although the Jordanian government provides farmers feed subsidy, the feed cost accounted for the biggest share $(75 \%)$ of the total variable costs, the averages of benefit-cost ratio in both systems of farms without feed subsidy seemed to be not economically acceptable. The economic success parameters (GM1, GM2, and NB) of farms without feed subsidy in the transhumant and sedentary systems would be more negatively affected compared to subsidized farms. GM1, GM2 and NB values of small ruminant production were more negative for most farmers with unsubsidized feed prices compared to those with subsidized feed prices in the present study, which was mainly due to high variable costs in general and feed cost in particular. The higher economic efficiency in terms of GM1 per head observed in the transhumant system is mainly due to better animal market accessibility and subsequently higher selling prices of animals in this system as compared to the sedentary system. Moreover, keeping large flock size with high off-take rate in the transhumant system compared to sedentary did hardly influence GM1 per flock, probably due to high variable costs to maintain larger flock sizes. However, there were farms that remain profitable even without subsidy, this could be ascribed to adopt technical strategies and managerial choices such as keeping high productive and fertile sheep or goat breeds, keeping large flock size, improving production level, feed selfsufficiency and adequate market accessibility.

The economic efficiency reported in this study would probably be increased in two production systems by reducing feed price, retaining feed subsidy, keeping larger flock size and increasing offtake rate. Owning larger flock size increases the total cash revenues, utilization of more products from animals, in-kind benefits and intangible socio-economic benefits of small ruminants 
and in turn the economic success and food security of households. If feed subsidy is fully removed, the negative economic implications are expected to be aggravated in the future in both production systems especially during seasons when the vegetation on the rangeland at minimum. A previous study (Abu Zanat \& Tabbaa, 2004) showed that drought and removal feed subsidies negatively impacted the small ruminant production. In 1996, the Jordanian government suddenly removed the subsidy on livestock feed, causing the price of feed to jump from 85 USD to around 130 USD per ton (Al-Tabini et al., 2012). Increasing feed price is usually opposed by farmers and should be usually evaluated by the government prior to an increase in feed pricing. However, the government sometimes reduce the percentage of subsidized price for feed and justifies that to the manipulation in having actual livestock holdings by farmers (having fake holdings) e.g. due to the exporting the livestock to neighbour countries, slaughtering the animals during the religious festival (Eid Aldha), normal occasions and mortalities during the year.

Different coping strategies have been suggested by farmers to reduce risks related tothe problem of feed subsidy removal. These include reducing the quantity of feed supplied, using low quality fodders, changing ration composition or reducing the flock size. In 1996, when the Jordanian government removed the subsidy on livestock feed, the livestock owners in the Badia region adapted to that situation by reducing the flock size by selling some animals to increase cash liquidity in order to feed the rest of the flock which in turn the family income affected adversely (Al-Tabini et al., 2012). Similarly, Jetter (2008) reported that, as a consequence of feed subsidy removal, many farmers in the Northern Badia of Jordan sold off their whole flock or reduced their flock sizes to feed the rest of the flocks. The reduction in the number of livestock was closely linked to feeding subsidy removal. During the period of time from 1996 to 1999 , the goat and sheep population apparently decreased as a consequence of feed subsidy lifting and drought then started to rise after retaining the subsidy. This caused a further drop in the market price of animals due to the oversupply in the market and a substantial rise in production costs, and consequently a decrease in the profitability of livestock production. Moreover, due to high feed cost as a result of feed subsidy removal and shortage of rangeland, farmers reduced the share of feed assigned for each head, which had a negative impact on health, reproductive efficiency and productivity of livestock (Jetter, 2008). Furthermore, nutritional qualities and composition of animal feed rations could also be affected. The ingredients used in producing a well-balanced and high energy ration will be replaced with other low-quality ingredients, and in turn, lower feed conversion efficiency. It is most profitable for farmers to continue to offer a feed with low-cost ingredients which have a negative impact on livestock health and production due to malnutrition.

\section{Conclusions}

This study revealed that under prevailing conditions of forage and rangeland shortage in Jordan, the impact of fully feed subsidy elimination for the livestock sector would aggravate the problem due to fact that feed cost constitutes $75 \%$ of the total variable costs and dynamic increase in the market prices of feeds. All the parameters of the economic efficiency of small ruminant production were found to be different between farms with subsidy retained and without feed subsidy among production systems. Hence, removing the subsidies is likely to exacerbate the inefficiency in the small ruminant production by accentuating feed inadequacy. However, the variation in feed purchasing and the consequent variation in animal productivity after the variation of feed market price should be considered in analysis of farm efficiency. Technical strategies and managerial choices such as keeping high productive sheep or goat breeds, increasing flock size, improving production level, better market accessibility and feed self-sufficiency are required to sustain small ruminant production without feed subsidy.

\section{Acknowledgments}

Funding the research $(107039 / 2017)$ by Deanship of Scientific Research at Al-Balqa Applied University is greatly appreciated. All contributions provided by the northern Badia people in data collection are gratefully acknowledged.

\section{Conflict of interest}

The authors declare that they have no conflict of interest.

\section{References}

Abu-Zanat MM, Migdady HA, Tabbaa MJ (2005) Production systems of small ruminants in middle Badia of Jordan.Dirasat: Agricultural Sciences 32:205-214.

Abu Zanat MMW, Tabbaa M (2004) Effect of drought on feed resources and performance ofsmall ruminants in the Northern Badia of Jordan. Dirasat: Agricultural Sciences32:347-354.

Al-Atiyat RM (2014) Role of small-scale dairy sector in food security and poverty alleviation. Food, Agriculture and Environment12:427-433.

Al-Atiyat RM, Tabbaa MJ (2009) Role of livestock in poverty alleviation and food security: A review study. In: Proceeding of Jordan Society of Scientific Research, Amman, Jordan.

Al-Karaki GN, Al-Momani N (2011) Evaluation of Some Barley Cultivars for Green Fodder Production and Water Use Efficiency under Hydroponic Conditions. Jordan Journal of Agricultural Sciences 7:448-457. 
Al-Khaza'leh J, Reiber C, Al Baqain R, Valle Zárate A (2015a) Drinking water sources, availability, quality, access and utilization for goats in the Karak Governorate, Jordan. Tropical Animal Health and Production 47:163-169.

Al-Khaza'leh J, Reiber C, Al Baqain R, Valle Zárate A (2015b) A comparative economic analysis of goat production systems in Jordan with an emphasis on water use. Livestock Research for Rural Development 27 (5), http://www.lrrd.org/lrrd27/5/khaz27081.html, accessed on 01 February 2020.

Alrousan L (2009) Goat production in Jordan. Proc. the 24th Ann. Goat Field Day, Langston Uni., Oklahoma, USA, pp. 33-40.

Alshdaifat SN, Obeidat BS (2019) The impact of feeding corn dried distillers grains with solubles on milk yield and composition in lactating Awassi ewes and digestibility and $\mathrm{N}$ partitioning in Awassi ewe lambs. Italian Journal of Animal Science 18:522-529.

Al-Tabini R, Al-Khalidi K, Al-Shudiefat M (2012)Livestock, medicinal plants and rangeland viability in Jordan's Badia, through the lens of traditional and local knowledge. Pastoralism: Research, Policy and Practice 2: 1-16.

Bergmann R, Ludbrook J, Spooren WPJM (2000) Different outcomes of the Wilcoxon-Mann-Whitney test from different statistics packages. The American Statistician 54: 72-77.

Central Bank of Jordan (2017) Publication and statistics, statistical database, interest rate structure for 2016/2017. Amman. Jordan.

Department of Statistics (2017) Statistics by sector, agriculture, surveys, livestock for 2016-2017.http://www.dos.gov.jo, accessed on 01 March 2019.
Jetter C (2008) An assessment of subsidy removal effects on and future sustainability for livestocksector of in the Northern Jordanian Badi. Independent Study Project (ISP) Collection. Paper 7.2019.https://digitalcollections.sit.edu/isp_collection/7/, accessed on 01 October.

Kristjanson P, Tyner WE (1992) Impacts of feed ingredient subsidy removal and concurrent trade liberalization in Tunisia. Agricultural Economics 7: 331-339.

Ministry of Agriculture (2016) Statistical annual report 2016, Amman, Jordan.

Ministry of Industry Trade and Supply (2018) Annual report 2018, Amman, Jordan.

Obeidat BS (2018) Influence of corn-dried distiller's grain with solubles on growth performance and blood metabolites of Awassi lambs offered a concentrate diet. Italian Journal of Animal Science17:636-642.

Obeidat BS, Awawdeh MS, Kridli RT, Al-Tamimi HJ, Ballou MA, Obeidat MD, Abu Ishmais MA, Al-Lataifeh FA, Subih HS (2014) Feeding corn silage improves nursing performance of Awassi ewes when used as a source of forage. Animal Feed Science and Technology 192:24-28.

Obeidat B, Shdaifat M (2013) Partial substitution of barley grain with ProsopisJuliflora pods in lactating Awassi ewes' diets: effect on intake, digestibility, and nursing performance. Small Ruminant Research 111:50-55.

SAS Institute (2012) Base SAS ${ }^{\circledR} 9.3$ Procedures Guide: Statistical Procedures, Second Edition. SAS Institute Inc, Cary, NC, USA. 